\title{
URBAN WASTEWATER EFFLUENT INCREASES ANTIBIOTIC RESISTANCE GENE CONCENTRATIONS IN A RECEIVING NORTHERN EUROPEAN RIVER
}

Björn Berglund, Jerker Fick and Per-Eric Lindgren

\section{Linköping University Post Print}

\section{Tweet}

N.B.: When citing this work, cite the original article.

Original Publication:

Björn Berglund, Jerker Fick and Per-Eric Lindgren, URBAN WASTEWATER EFFLUENT INCREASES ANTIBIOTIC RESISTANCE GENE CONCENTRATIONS IN A RECEIVING NORTHERN EUROPEAN RIVER, 2015, Environmental Toxicology and Chemistry, (34), 1, 192-196.

http://dx.doi.org/10.1002/etc.2784

Copyright: Wiley: 12 months http://eu.wiley.com/WileyCDA/

Postprint available at: Linköping University Electronic Press http://urn.kb.se/resolve?urn=urn:nbn:se:liu:diva-113727 
1 Running title: Wastewater increases antibiotic resistance in receiving

2 river

3

4 Corresponding author: Björn Berglund

5 Address: Hälsouniversitetet, Medicinsk mikrobiologi, Plan 12,

6581 85, Linköping, Sweden

7 Telephone number: +46101032616

$8 \quad$ Fax: +4610 1034789

9 Email: bjorn.berglund@liu.se 
21 Urban wastewater effluent increases antibiotic resistance gene

22 concentrations in a receiving Northern European river

24 Björn Berglund ${ }^{* \dagger}$, Jerker Fick ${ }^{\ddagger}$, Per-Eric Lindgren ${ }^{\dagger, \S}$

25

$26 \dagger$ Linköping University, Division of Medical Microbiology, Department of Clinical and

27 Experimental Medicine, Linköping, Sweden

$28+$ Department of Chemistry, Umeå University, Umeå, Sweden

$29 \S$ Department of Microbiology, Medical Services, County Hospital Ryhov, Jönköping, Sweden 
37 *Address correspondence to bjorn.berglund@liu.se.

38

39

40

41

42

43

44

45

46

47

48

49

50 


\section{Abstract}

52

53 important advances in modern medicine. The environment is likely to play an important role in

54 dissemination of antibiotic resistance genes (ARGs) among both environmental and pathogenic bacteria.

55 Wastewater treatment plants (WWTPs) accumulate both chemical and biological waste from the

56 surrounding urban milieu and have therefore been viewed as potential hotspots for dissemination and

57 development of antibiotic resistance. To assess the effect of wastewater effluent on a river which flows

58 through a Swedish city, sediment and water samples were collected from Stångån River, both upstream

59 and downstream of an adjacent WWTP over three months. Seven ARGs and the integrase gene on class 1

60 integrons were quantified in the collected sediment using real-time PCR. Liquid chromatography-mass

61 spectrometry was used to assess the abundance of ten different antibiotics in the water phase of the

62 samples. The results showed an increase in ARGs and integrons downstream of the WWTP. The measured

63 concentrations of antibiotics were low in the water samples from Stångån River, suggesting that selection

64 for ARGs did not occur in the surface water. Instead, the downstream increase in ARGs is likely to be due

65 to accumulation of genes present in the treated effluent discharged from the WWTP.

66

67 Keywords: Antibiotic resistance genes, Antibiotics, Integrons, Quantitative real-time PCR, Wastewater 
The increasing prevalence of antibiotic resistance among human pathogenic bacteria is a

75 major global threat. Bacterial infections, which are currently cured readily by treatment with antibiotics,

76 may become difficult, if not impossible, to treat. Furthermore, the lack of access to efficient antibiotics

77 may make routine medical procedures such as surgery and chemotherapy in cancer treatment extremely

78 risky [1]. Human use and misuse of antibiotics are likely to have significantly contributed to the

79 emergence of antibiotic resistance. Recently, much attention has been directed to the role of

80 environmental bacteria. Many antibiotic resistance genes (ARGs) carried by pathogenic bacteria are

81 thought to have originated in environmental bacteria [2], and ARGs have been found to be ubiquitous in a

82 large range of environments [3], including those considered pristine [4]. In particular, environments

83 exposed to high concentrations of antibiotics have been demonstrated to also contain high concentrations

84 of ARGs [5,6]. It seems plausible that perturbations of environmental ecosystems caused by human

85 antibiotic contamination may play an important role in the dissemination of clinical antibiotic resistance

$86[7,8]$.

Wastewater treatment plants (WWTPs) and their subsequent effluent are environments in which human bacteria and antibiotics from the urban milieu mix together with environmental bacteria,

89 making them potential hot spots for both development and dissemination of ARGs [9,10]. WWTPs are not

90 always efficient at removing antibiotics; these and other pharmaceuticals are often found in concentrations

91 ranging from $\mathrm{ng} / \mathrm{L}$ to low $\mu \mathrm{g} / \mathrm{L}$ in wastewaters [11]. ARGs too, have been reported to be ubiquitous in

92 wastewater [3,12]. Insufficiently treated industrial waste has also been observed to elevate levels of

93 antibiotics in the environment $[6,13]$.

Class 1 integrons are genetic assembly platforms capable of incorporating and utilising

95 gene cassettes from the environment. These gene cassettes can encode a wide range of functions including

96 antibiotic resistance. Class 1 integrons are widely associated with mobile genetic elements which make 
97 them ideal for disseminating ARGs in a bacterial community [14]. Several studies have shown that class 1

98 integrons are more abundant in anthropogenically affected environments which indicate that these genetic

99 elements are important in mediating ARGs in the environment $[15,16]$.

In this study, we aimed to assess the impact of WWTP effluent on relative abundances of

ARGs and integrons in the receiving river. Antibiotic and ARG concentrations were investigated in a river the WWTP which receives wastewater from the city.

\section{MATERIAL AND METHODS}

Stångån is a river in the southern part of Sweden. It is $202 \mathrm{~km}$ in length and passes through the city of Linköping (population: 150,000) just before its outlet in the lake, Roxen. From its source to of incoming and outgoing water of the WWTP was $46,000 \mathrm{~m}^{3} / \mathrm{d}$ and the hydraulic retention time was 12 $13 \mathrm{~h}$. Water and sediment samples were gathered from five sampling locations (R1-R5) in the river. R1

112 was approximately $1 \mathrm{~km}$ upstream of the WWTP, and R2 was located just prior to the river passing the

113 WWTP. R3 was located in the river just as it passed the WWTP, R4 was approximately $1 \mathrm{~km}$ downstream 114 of the WWTP, and R5 approximately $2.5 \mathrm{~km}$ downstream of the WWTP. Grab-samples were collected in 115 2011, once in October, November and December each. The average flow of the river during these months 116 was $6.6 \mathrm{~m}^{3} / \mathrm{s}$. Effluent from the WWTP was also collected at each time point. The sediment phase of the 117 samples was pre-treated within $4 \mathrm{~h}$ after sampling whereas the water phase of the samples was frozen in $11820{ }^{\circ} \mathrm{C}$ before chemical analysis. 
121 for $30 \mathrm{~min}$ in $5,000 \mathrm{~g}$. Pellets were stored overnight in $-20{ }^{\circ} \mathrm{C}$ before subsequent DNA extraction. DNA

122 was extracted from the pellets accumulated from the water samples with the FastDNA SPIN Kit for Soil

123 and the FastPrep Instrument (MP Biomedicals). Extracted DNA was stored in $-20{ }^{\circ} \mathrm{C}$ before subsequent

124 analyses.

Quantification of $16 S$ rRNA genes, ARGs and intII

Quantitative real-time PCR was used for gene quantification on the DNA extracted from

127 the samples. The genes which were quantified were sulI (sulphonamide resistance gene), $d f r l$

128 (trimethoprim resistance gene), ermB (macrolide/lincosamide/streptogramin B resistance gene), tetA and

$129 t e t B$ (tetracycline resistance genes), $v a n B$ (vancomycin resistance gene), qnrS (quinolone resistance gene)

130 and intII, the integrase gene on class 1 integrons. 16S rRNA gene content was quantified and used to

131 normalise the quantified number of genes in each sample. All PCRs were carried out on a CFX96 ${ }^{\mathrm{TM}}$ Real-

132 Time PCR Detection System (Bio-Rad Laboratories). Quantification method, primers, primer

133 concentrations and thermal cycling protocols for each gene were used as described in Berglund et al. [17].

\section{Antibiotic quantification}

Antibiotic concentrations in the water samples were determined by chemical analysis using

an in-line SPE column coupled to liquid chromatography-tandem mass spectrometry, as described in Khan

137 et al. [6]. In short, a triple stage quadrupole MS/MS TSQ Quantum ULTRA EMR (Thermo Fisher

138 Scientific) coupled with an Accela and a Surveyor LC Pump (Thermo Fisher Scientific) and a PAL HTC

139 autosampler (CTC Analytics AG) were used as analytical system.

\section{Statistical analysis}

A Friedman test followed by a Dunn's Multiple Comparisons test was used to assess 
143 correction were used to assess differences in concentration of specific genes between sites upstream and 144 downstream of the WWTP. All statistical analyses were carried out using Prism 5 for Windows v.5.00.

\section{RESULTS}

Quantification of antibiotic resistance genes

ARGs were detected and quantified in water samples taken from all sampling points at all

148 sampling times (Figure 1). Overall, ARG concentrations were lower at the upstream sites R1 and R2, than

149 at the site R3, downstream of the WWTP $(p<0.01$ and $p<0.001$ respectively). The ARGs which were

150 found in the highest concentrations were $s u l I$, tetA and ermB. Concentrations of ermB were significantly

151 higher downstream than upstream of the WWTP $(p<0.01)$, whereas concentrations of sulI and tetA were

152 more than ten times higher downstream compared to upstream of the WWTP $(p<0.01)$. ARGs $t e t B, d f r l$

153 and $v a n B$ were found in comparatively lower concentrations, particularly at the upstream sites at which

$154 \quad t e t B$ and $d f r l$ were detected below the quantification limit. vanB was only detected at one time point

155 among the upstream sampling locations. ARG $q n r S$ was not detected at any sampling location. All ARGs

156 (except qnrS) were detected and quantified in the WWTP effluent at concentrations at similar levels as in

157 the downstream sites.

The integrase gene intIl was detected and quantified in all samples (Figure 1).

159 Concentrations were significantly higher downstream of the WWTP than upstream $(p<0.001)$. In general,

160 intIl concentrations at the downstream sites were higher by approximately one order of magnitude

161 (around $10^{4}$ genes / 106 $16 \mathrm{~S}$ rDNA copies for the upstream sites and $10^{5}$ genes $/ 10^{6} 16 \mathrm{~S}$ rDNA copies for

162 the downstream sites). intIl concentrations in the WWTP effluent were of similar magnitude to the

163 concentrations found at the downstream sites.

\section{Quantification of antibiotics and other pharmaceuticals}



wastewater effluent (10, 3 and $3 \mathrm{ng} / \mathrm{L}$, respectively) while the average concentration of TRI was $24 \mathrm{ng} / \mathrm{L}$, about an order of magnitude higher than the detection limit (3 ng/L). At the downstream sites, CLA, CLI and TRI were found sporadically, at concentrations similar to those in the wastewater effluent. No antibiotics were detected in any of the upstream sampling locations. NOR, OFX, OXY, ROX, SUL and

171 TET were not detected at any sampling location. sampling locations, very close to the detection limit (Supplemental Data, Table S1).

\section{DISCUSSION}

ARGs and integrons were quantified in sediments from Stångån River, Sweden, both upstream and downstream of a WWTP receiving wastewater from the adjacent city Linköping. Both for ARG abundance in general and when comparing abundances of specific genes, the locations downstream of the WWTP displayed significantly higher abundance than upstream locations. The difference was most pronounced for genes sulI and tetA. Several other studies have reported similar trends in ARG abundance upstream and downstream of anthropogenic perturbations. In [6], ARGs were quantified in river sediments in a river upstream and downstream of a large Pakistani city. ARG concentrations were consistently higher downstream than upstream. Abundances of sulI was approximately $10^{3}$ genes $/ 10^{6} 16 \mathrm{~S}$ rDNA copies upstream and $10^{5}$ genes $/ 10^{6} 16 \mathrm{~S}$ rDNA copies downstream which is higher compared to this study. The upstream abundances of tetA and $d f r l$ were not high enough to be detected, which can be compared to the upstream abundances in this study in which $d f r l$ was detectable but not quantifiable and tetA was found in the order of magnitude of $10^{0}$ genes / $10^{6} 16 \mathrm{~S}$ rDNA. The downstream abundances of 

higher concentrations. The abundance of sulI in river sediments has been observed to increase in a river in 191 the United States, at a pristine site and downstream of a range of human activities [18]. Concentrations 192 increased from approximately $10^{0}$ to $10^{2}$ genes / $10^{6} 16 \mathrm{~S}$ rDNA copies from the pristine site to the 193 perturbed sites, overall somewhat lower abundances than in this study. In [19], ARGs were measured in 194 sediments of a river upstream and downstream of a WWTP in Spain. sulI was found at similar 195 concentrations upstream and downstream, approximately $5 \times 10^{3}$ genes / $10^{6} 16 \mathrm{~S}$ rDNA copies. erm $B$ was 196 measured at higher concentrations downstream than upstream, although at both locations at lower 197 concentrations than in this study (by approximately one order of magnitude). It should be noted that these 198 studies were done in different areas of the world. Factors such as temperature and nutrient availability may 199 be important in resistance development, and these factors were likely different between the compared 200 locations.

Class 1 integron gene intIl was found in all samples with a significant increase in

202 abundance from upstream to downstream sites. Although integrons are ubiquitous in nature, several 203 studies have reported that human contamination increases the abundance of integrons $[15,16,20]$. In [6], 204 intI abundances were reported to increase in river sediments as the river passed a large Pakistani city, 205 although concentrations were higher than in this study with downstream concentrations reaching as high 206 as $8 \times 10^{5}$ genes $/ 10^{6} 16 \mathrm{~S}$ rDNA copies.

Antibiotics were not detected in the surface water at locations upstream of the WWTP.

208 However, antibiotics were detected in both wastewater effluent and in sample locations downstream of the 209 WWTP, although only four (CIP, CLA, CLI and TRI) of the ten analysed antibiotics, and at very low 210 concentrations. TRI, which was found at the highest concentrations, had a mean concentration $(n=3)$ as 211 low as $38 \mathrm{ng} / \mathrm{L}$ (highest concentration quantified was $47 \mathrm{ng} / \mathrm{L}$ ) in the effluent and $10 \mathrm{ng} / \mathrm{L}(\mathrm{n}=3)$ in the 212 surface water. None of the other antibiotics quantifiable were found at concentrations above $20 \mathrm{ng} / \mathrm{L}$. The 213 non-antibiotic pharmaceuticals analysed showed a similar trend to the antibiotics, the few pharmaceuticals 
214 detected were quantified at low concentrations and only three were detected at the upstream locations. In

215 [21], minimum selective concentrations for test strains of bacteria were found to be $10^{6} \mathrm{ng} / \mathrm{L}, 1.5 \times 10^{4}$

$216 \mathrm{ng} / \mathrm{L}$ and $10^{2} \mathrm{ng} / \mathrm{L}$ for streptomycin, TET and CIP respectively. This can be compared to this study, where

217 TET could not be detected with a detection limit at $20 \mathrm{ng} / \mathrm{L}$, and CIP which was quantified at about half

218 the minimum selective concentration. In [17], selection for ARGs could not be observed in a wetland

219 bacterial community when exposed to a mixture of antibiotics including concentrations of CLA, CLI and

220 TRI measured up to $250 \mathrm{ng} / \mathrm{L}, 66 \mathrm{ng} / \mathrm{L}$ and $420 \mathrm{ng} / \mathrm{L}$, respectively. It may be reasonable to assume that the

221 low antibiotic concentrations measured in the effluent and downstream sites do not select for ARGs.

222 Consequently, the observed increase in ARG abundance from upstream to downstream sites likely stem

223 from the WWTP. The ARG abundances in the wastewater may originate either from selection in the

224 wastewater treatment process (e.g. due to exposure to antibiotics) or by accumulation of ARGs via the

225 received waste from the urban environment.

It should be noted that, since the antibiotics are measured in the water phase, the

227 concentrations represent only the concentrations in the water at the moment the samples were taken. As

228 such, sedentary bacteria on the examined sediments may be exposed to a range of antibiotic

229 concentrations well outside of the measured concentrations. The concentration of antibiotics in the

230 untreated wastewater is also likely higher than the concentration in the effluent. This could mean that the

231 bacteria in the WWTP are exposed to antibiotic concentrations higher than those measured in the effluent.

232 On the other hand, the measured genes include both extracellular DNA and genes within living bacteria.

233 Extracellular DNA can avoid environmental degradation by adhesion to sand and clay particles [22]. The

234 ARGs from extracellular DNA have been reported to be greater than ARGs from intracellular DNA in a

235 Chinese river basin [23]. In the case that a significant portion of the measured ARGs in the sediment are

236 extracellular, the concentration of antibiotics in the surrounding water may have little to no effect on the

237 selection and proliferation of ARGs. 
239 in the dissemination and spread of antibiotic resistance. Therefore it is important to elucidate the ecology

240 and dynamics of ARG dissemination. Anthropogenic contamination and environmental perturbations have

241 been linked to increases in ARGs and for this reason WWTPs have been regarded as potential hotspots for

242 the dissemination of these genetic elements. The results of this study showed an increase in ARG

243 abundances in a river downstream of a WWTP. The low antibiotic concentrations in the river and WWTP

244 effluent indicate that selection for ARGs does not occur in the surface water. Instead, the WWTP is the

245 likely point source of ARGs. Further studies are needed to assess the origins of these ARGs, to determine

246 if selection for ARGs occurs in the wastewater treatment process or whether the accumulated ARGs

247 originate in the recipient waste coming from other sources (e.g. hospitals).

\section{SUPPLEMENTAL DATA}

249 The concentrations of 93 different pharmaceuticals (including ten different antibiotics) were analysed in 250 the surface water and WWTP effluent samples and are presented in Supplemental Data, Table S1.

\section{ACKNOWLEDGEMENT}

We thank the staff at Tekniska verken i Linköping AB, Linköping, for fruitful collaboration and kind sample provision. This project was funded by the Swedish Research Council for Environment,

254 Agricultural Sciences and Spatial Planning (Formas, contract number 210-2006-2132) and the Foundation

255 for Strategic Environmental Research (MISTRA) (within the research project MISTRAPHARMA).

\section{REFERENCES}

1. Laxminarayan R, Duse A, Wattal C, Zaidi AK, Wertheim HF, Sumpradit N, Vlieghe E, Hara GL, Gould IM, Goossens H, Greko C, So AD, Bigdeli M, Tomson G, Woodhouse W, Ombaka E, Peralta AQ, Qamar FN, Mir 
2. Martínez JL. 2008. Antibiotics and antibiotic resistance genes in natural environments. Science 321:365367.

3. Zhang XX, Zhang T, Fang HH. 2009. Antibiotic resistance genes in water environment. Appl Microbiol Biotechnol 82:397-414.

4. D'Costa VM, King CE, Kalan L, Morar M, Sung WW, Schwarz C, Froese D, Zazula G, Calmels F, Debruyne R, Golding GB, Poinar HN, Wright GD. 2011. Antibiotic resistance is ancient. Nature 477:457-461.

5. Kristiansson E, Fick J, Janzon A, Grabic R, Rutgersson C, Weijdegård B, Söderström H, Larsson DG. 2011 Pyrosequencing of antibiotic-contaminated river sediments reveals high levels of resistance and gene transfer elements. PLoS One 6:e17038.

6. Khan GA, Berglund B, Khan KM, Lindgren PE, Fick J. 2013. Occurrence and abundance of antibiotics and resistance genes in rivers, canal and near drug formulation facilities-a study in Pakistan. PLoS One 8:e62712.

7. Martínez JL. 2009. The role of natural environments in the evolution of resistance traits in pathogenic bacteria. Proc Biol Sci 276:2521-2530.

8. Wright GD. 2010. Antibiotic resistance in the environment: a link to the clinic? Curr Opin Microbiol 13:589594.

9. Baquero F, Martínez JL, Cantón R. 2008. Antibiotics and antibiotic resistance in water environments. Curr Opin Biotechnol 19:260-265.

10. Pruden, A. 2014. Balancing water sustainability and public health goals in the face of growing concerns about antibiotic resistance. Environ Sci Technol 48:5-14.

11. Segura PA, François M, Gagnon C, Sauvé S. 2009. Review of the occurrence of anti-infectives in contaminated wastewaters and natural drinking waters. Environ Health Perspect 117:675-684.

12. LaPara TM, Burch TR, McNamara PJ, Tan DT, Yan M, Eichmiller JJ. 2011. Tertiary-treated municipal wastewater is a significant point source of antibiotic resistance genes into Duluth-Superior Harbor. Environ Sci Technol 45:9543-9549.

13. Fick J, Söderström H, Lindberg RH, Phan C, Tysklind M, Larsson DG. 2009. Contamination of surface, ground, and drinking water from pharmaceutical production. Environ Toxicol Chem 28:2522-2527. 
14. Mazel D. 2006. Integrons: agents of bacterial evolution. Nat Rev Microbiol 4:608-620.

15. Wright MS, Baker-Austin C, Lindell AH, Stepanauskas R, Stokes HW, McArthur JV. 2008. Influence of industrial contamination on mobile genetic elements: class 1 integron abundance and gene cassette structure in aquatic bacterial communities. ISME J 2:417-428.

16. Gaze WH, Zhang L, Abdouslam NA, Hawkey PM, Calvo-Bado L, Royle J, Brown H, Davis S, Kay P, Boxall AB, Wellington EM. 2011. Impacts of anthropogenic activity on the ecology of class 1 integrons and integronassociated genes in the environment. ISME J 5:1253-1261.

17. Berglund B, Khan GA, Weisner SEB, Ehde PM, Fick J, Lindgren PE. 2014. Efficient removal of antibiotics in surface-flow constructed wetlands, with no observed impact on antibiotic resistance genes. Sci Tot Environ 476-477:29-37.

18. Pei R, Kim SC, Carlson KH, Pruden A. 2006. Effect of river landscape on the sediment concentrations of antibiotics and corresponding antibiotic resistance genes (ARG). Water Res 40:2427-2435.

19. Marti E, Jofre J, Balcazar JL. 2013. Prevalence of antibiotic resistance genes and bacterial community composition in a river influenced by a wastewater treatment plant. PLoS One 8:e78906.

20. Rosewarne CP, Pettigrove V, Stokes HW, Parsons YM. 2010. Class 1 integrons in benthic bacterial communities: abundance, association with Tn402-like transposition modules and evidence for coselection with heavy-metal resistance. FEMS Microbiol Ecol 72:35-46.

21. Gullberg E, Cao S, Berg OG, Ilbäck C, Sandegren L, Hughes D, Andersson DI. 2011. Selection of resistant bacteria at very low antibiotic concentrations. PLoS Pathog 7:e1002158.

22. Davison, J. 1999. Genetic exchange between bacteria in the environment. Plasmid 42:73-91.

23. Mao D, Luo Y, Mathieu J, Wang Q, Feng L, Mu Q, Feng C, Alvarez PJ. 2014. Persistence of extracellular DNA in river sediments facilitates antibiotic resistance gene propagation. Environ Sci Technol 48:71-78.

24. Grabic R, Fick J, Lindberg RH, Fedorova G, Tysklind M. 2012. Multi-residue method for trace level determination of pharmaceuticals in environmental samples using liquid chromatography coupled to triple quadrupole mass spectrometry. Talanta 100:183-195. 
315 Figure 1. Antibiotic resistance genes (ARGs) were measured from collected sediments from Stångån River. Sites R1 316 and R2 are upstream, and sites R3, R4 and R5 are downstream of the wastewater treatment plant (WWTP). 'E'

317 sampling location denotes the wastewater effluent. Presented values are means over three months. Error bars

318 denote the standard error of the mean. Note that linearity and magnitude of the scales differ between the graphs.

319 '*' denotes; detected, below quantification limit.

321 Figure 2. Antibiotics were quantified from collected water samples from Stångån River. Sites R1 and R2 are

322 upstream, and sites R3, R4 and R5 are downstream of the wastewater treatment plant (WWTP). 'E' sampling

323 location denotes the wastewater effluent. CIP: ciprofloxacin, CLA: clarithromycin, CLI: clindamycin, TRI:

324 trimethoprim. 

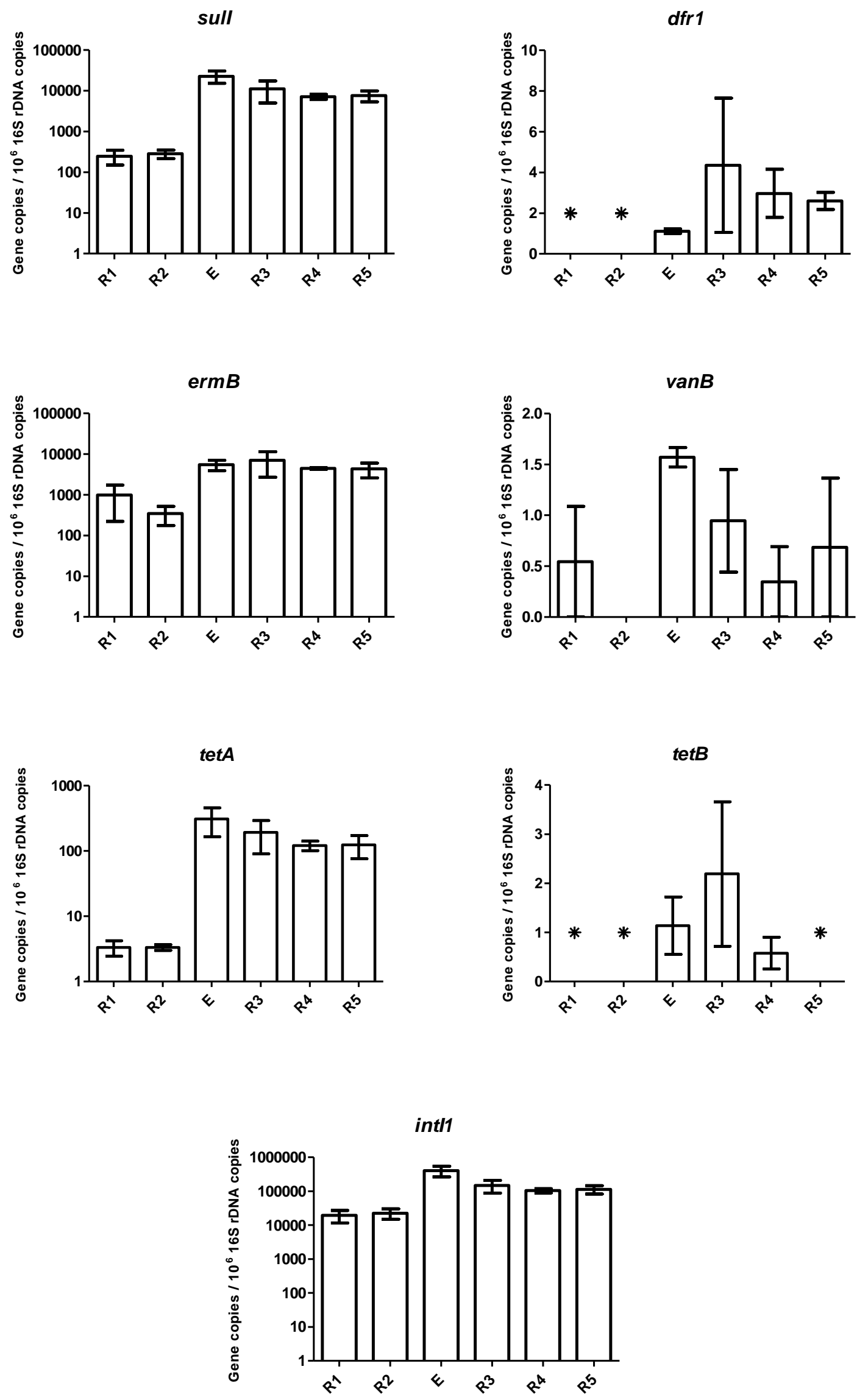


\section{October}

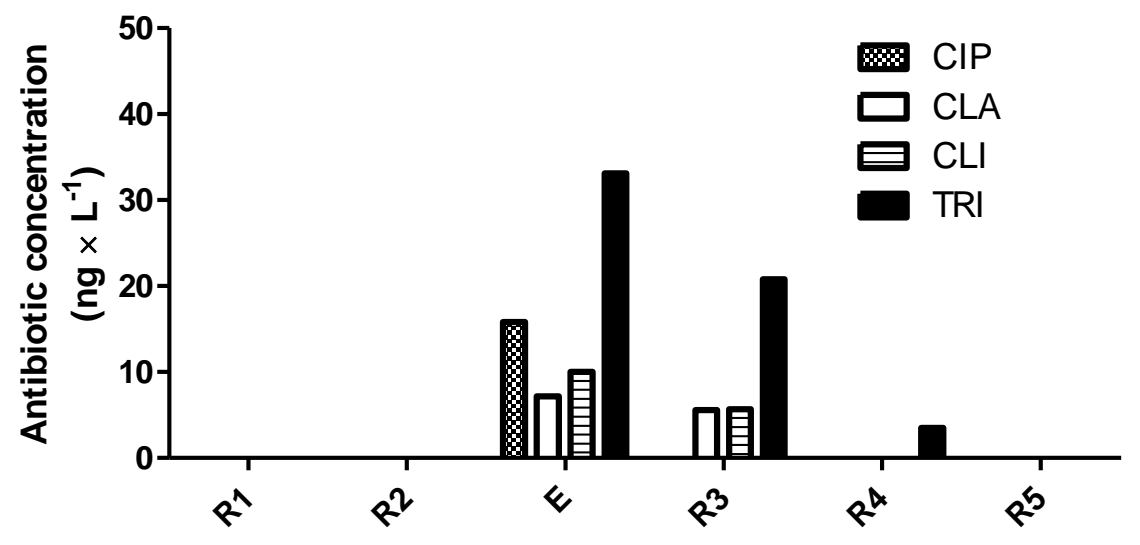

November

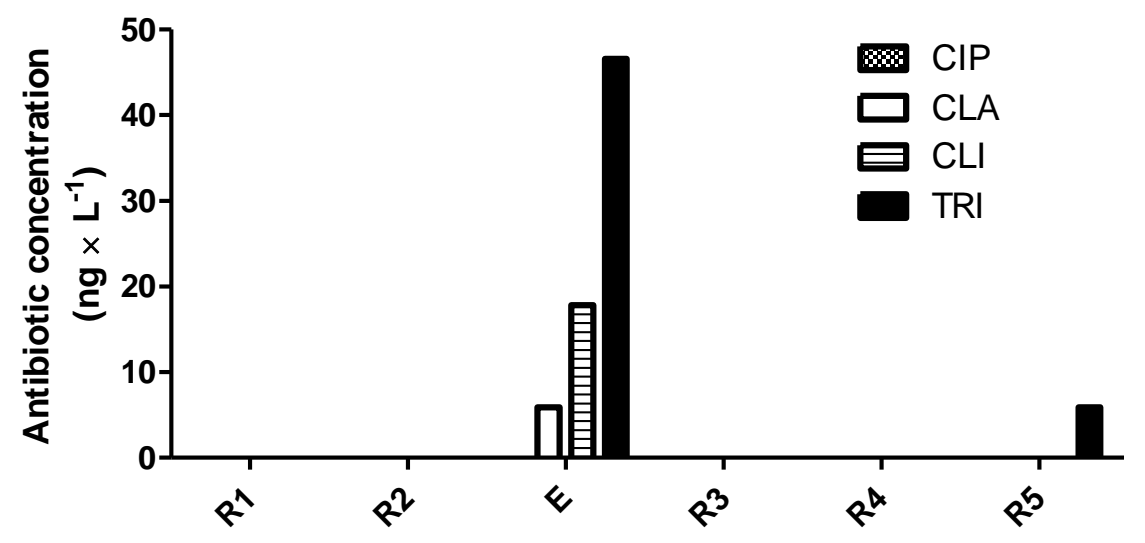

December

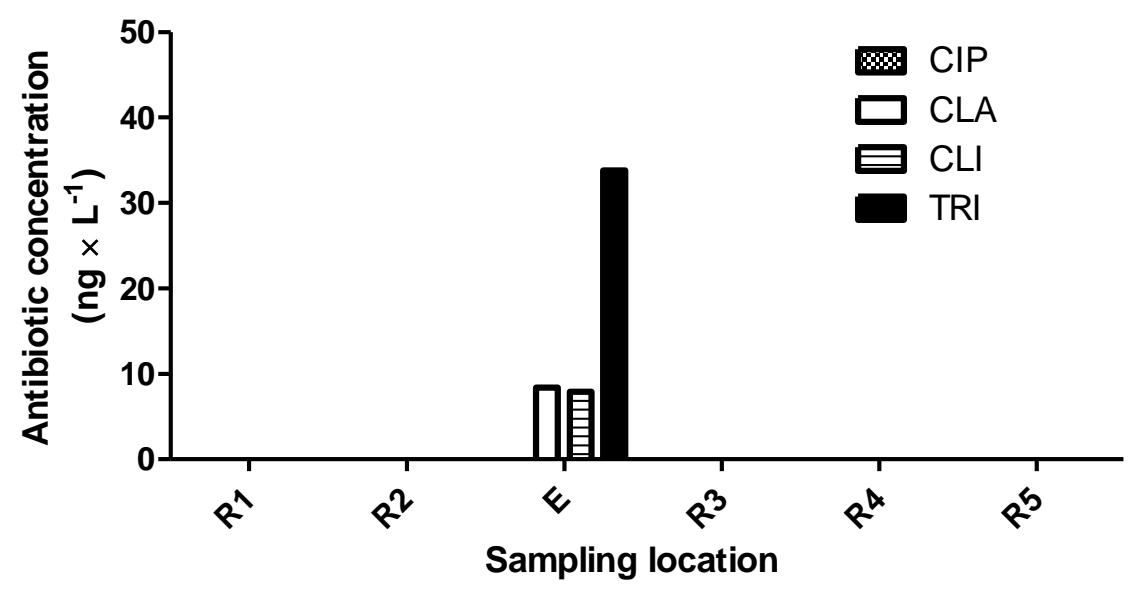


Table S1. The abundance of 93 different pharmaceuticals were analysed as described in Grabic et al. [24], in the water phase of the samples from the surface water (R1-R5) and WWTP effluent (E). Concentrations are given in ng/L. '-' denotes that the concentration of the given pharmaceutical was below the limit of quantification. Pharmaceuticals which were below the limit of quantification in all sampling points are omitted from the table. These are: alfuzosin, alprazolam, amiodarone, amytriptyline, atorvastatin, atracurium, azelastine, biperiden, bromocriptine, buprenorphine, bupropion, chlorpromazine, chlorprothixene, cilazapril, citalopram, clemastine, clomipramine, clonazepam, clotrimazol, cyproheptadine, desloratidin, dicycloverine, dihydroergotamine, diphenhydramine, donepezil, duloxetine, eprosartan, fenofibrate, fentanyl, finasteride, flunitrazepam, fluoxetine, flupentixol, fluphenazine, flutamide, glibenclamide, glimepiride, haloperidol, hydroxyzine, ketoconazole, levomepromazine, loperamide, maprotiline, meclozine, memantine, mianserin, miconazole, nefazodone, norfloxacin, ofloxacin, orphenadrine, oxytetracycline, paracetamol, paroxetine, perphenazine, pizotifen, promethazine, ranitidine, repaglinide, rosuvastatin, roxithromycine, sertraline, sulfamethoxazole, tamoxifen, telmisartan, terbutaline, tetracycline, trihexyphenidyl, verapamil, zolpidem. 


\begin{tabular}{|c|c|c|c|c|c|c|c|c|c|c|c|c|c|c|c|c|c|c|c|}
\hline (ng/L) & $\mathrm{LOQ}^{\mathrm{a}}$ & $\begin{array}{l}\text { Oct } \\
\text { R1 }\end{array}$ & $\begin{array}{l}\text { Oct } \\
\text { R2 }\end{array}$ & $\begin{array}{l}\text { Oct } \\
\text { R3 }\end{array}$ & $\begin{array}{c}\text { Oct } \\
\text { R4 }\end{array}$ & $\begin{array}{l}\text { Oct } \\
\text { R5 }\end{array}$ & $\begin{array}{c}\text { Oct } \\
E\end{array}$ & $\begin{array}{c}\text { Nov } \\
\text { R1 }\end{array}$ & $\begin{array}{c}\text { Nov } \\
\text { R2 }\end{array}$ & $\begin{array}{c}\text { Nov } \\
\text { R3 }\end{array}$ & $\begin{array}{c}\text { Nov } \\
\text { R4 }\end{array}$ & $\begin{array}{c}\text { Nov } \\
\text { R5 }\end{array}$ & $\begin{array}{c}\text { Nov } \\
E\end{array}$ & $\begin{array}{c}\text { Dec } \\
\text { R1 }\end{array}$ & $\begin{array}{c}\text { Dec } \\
\text { R2 }\end{array}$ & $\begin{array}{c}\text { Dec } \\
\text { R3 }\end{array}$ & $\begin{array}{c}\text { Dec } \\
\text { R4 }\end{array}$ & $\begin{array}{c}\text { Dec } \\
\text { R5 }\end{array}$ & $\begin{array}{c}\text { Dec } \\
\text { E }\end{array}$ \\
\hline Atenolol & 15 & - & - & 195.6 & 22.3 & 19.9 & 255.3 & - & - & - & - & 27.1 & 314.9 & - & - & - & - & - & 268.2 \\
\hline Bisoprolol & 3 & - & - & 4.4 & - & - & 6.5 & - & - & - & - & - & 9.5 & - & - & - & - & - & 4.9 \\
\hline Budesonide & 20 & - & - & - & - & - & - & 22.3 & - & - & - & - & - & - & - & - & - & - & - \\
\hline Carbamazepin & 8 & - & - & 77.8 & 9.1 & - & 93.3 & - & - & - & - & 12.0 & 124.2 & - & - & - & - & - & 83.8 \\
\hline Ciprofloxacin & 10 & - & - & - & - & - & 15.8 & - & - & - & - & - & - & - & - & - & - & - & - \\
\hline Clarithromycine & 3 & - & - & 5.6 & - & - & 7.2 & - & - & - & - & - & 5.9 & - & - & - & - & - & 8.4 \\
\hline Clindamycine & 3 & - & - & 5.7 & - & - & 10.0 & - & - & - & - & - & 17.8 & - & - & - & - & - & 7.9 \\
\hline Codeine & 15 & - & - & 41.3 & - & - & 53.3 & - & - & - & - & - & 68.4 & - & - & - & - & - & 45.6 \\
\hline Diclofenac & 10 & - & - & 26.0 & - & - & 40.4 & - & - & - & - & - & 47.7 & - & - & - & - & - & 30.1 \\
\hline Diltiazem & 2 & - & - & - & - & - & - & - & - & - & - & - & 2.2 & - & - & - & - & - & - \\
\hline Fexofenadine & 10 & - & - & 15.7 & - & - & 11.1 & - & - & - & - & - & 16.6 & - & - & - & - & - & 13.7 \\
\hline Flecainide & 2 & - & - & 15.0 & 2.4 & 1.9 & 23.2 & - & - & - & - & 2.3 & 36.1 & - & - & - & - & - & 26.9 \\
\hline Fluconazole & 8 & - & - & 93.6 & - & - & 139.6 & - & - & - & - & - & 118.6 & - & - & - & - & - & 100.8 \\
\hline Irbesartan & 3 & - & - & 7.4 & - & - & 8.8 & - & - & - & - & - & 12.1 & - & - & - & - & - & 9.7 \\
\hline Metoprolol & 15 & - & - & 116.8 & 16.7 & - & 154.5 & - & - & - & - & 22.7 & 204.0 & - & - & - & - & - & 134.4 \\
\hline Mirtazapine & 15 & - & - & - & - & - & - & - & - & - & - & - & 25.0 & - & - & - & - & - & - \\
\hline Naloxone & 2 & - & - & 10.8 & - & - & - & - & - & - & - & - & - & 4.7 & 6.9 & - & - & - & - \\
\hline Oxazepam & 10 & - & - & 11.6 & - & - & 14.2 & - & - & - & - & - & 17.9 & - & - & - & - & - & 13.3 \\
\hline Risperidone & 4 & 6.6 & - & - & - & - & - & - & - & - & - & - & - & - & - & - & - & - & - \\
\hline Sotalol & 15 & - & - & 32.7 & - & - & 44.7 & - & - & - & - & - & 53.4 & - & - & - & - & - & 39.4 \\
\hline Tramadol & 15 & - & - & 84.4 & - & - & 112.1 & - & - & - & - & - & 140.6 & - & - & - & - & - & 96.8 \\
\hline Trimethoprim & 3 & - & - & 20.8 & 3.5 & - & 33.1 & - & - & - & - & 5.9 & 46.6 & - & - & - & - & - & 33.8 \\
\hline Venlafaxine & 20 & - & - & 21.7 & - & - & 34.7 & - & - & - & - & - & 50.2 & - & - & - & - & - & 24.6 \\
\hline
\end{tabular}

a 'LOQ' denotes limit of quantification 